\title{
JEASP
}

Journal of English for Academic and Specific Purposes

Volume 4 Number 1, June, 2021

\section{EXPLORING TEACHERS AND STUDENTS' PERSPECTIVES TOWARD NEGOTIATED SYLLABUS IN ENGLISH LEARNING FOR SENIOR HIGH SCHOOL}

Imam Ghozali

Banun Havifah Cahyo Khosiyono ${ }^{2}$

Muhammad Ulil Abror ${ }^{3}$

(banuna.havifab90@gmail.com)

English Education, Graduate School, Sarjanawiyata Tamansiswa University ${ }^{123}$

\begin{tabular}{l} 
ARTICLE \\
\hline Keywords: \\
negotiated syllabus, \\
students'perspective, \\
teachers'perspective
\end{tabular}

\section{INTRODUCTION}

The government regulation of Indonesia number 19 of the year 2005 is stated that language education should develop language competence with special emphasis on reading and writing according to the literacy level set up for every level of education. To be more specifically, for the educational level of senior high school, the literacy level that should be achieved is the informational level to the implementation of language acquisition on English competence and performance in both formal and informal contexts. Both acquisitions are found in the curriculum and its syllabus designed by the Ministry of Education. Teachers and scholars need to develop the

\begin{abstract}
Designing language syllabus is one of the important processes in the English language teaching contexts. Ensuring both teachers and students' needs what and how their teaching and learning are applicable, negotiated syllabus can be proposed in teaching-learning processes. This study aims to find the teachers' and students' perspectives to determine whether aspects of the syllabus may be negotiable. Qualitative descriptive is used in this research. The participants involved were four English teachers and twenty students. Data were collected by using a questionnaire in the form of open-ended questions. The syllabus aspects that may be interested to negotiate according to Boon (2011) are course content, lesson aims, sequencing, material, homework, evaluation, methodology, groupings, and error correction. Both teachers and students believe the eleven areas could be negotiated. However, there are some debates in several areas. According to some teachers' perspectives, the area of material, homework, evaluation, and error correction are not needed to be negotiated. Besides, according to some students, the area of course content, lesson aim, sequencing, material, grouping, and error correction are the teachers' responsibilities.
\end{abstract}


JEASP

Journal of English for Academic and Specific Purposes

Volume 4 Number 1, June, 2021

competence and performance through the provided curriculum into a learning procedure to achieve learning objectives.

Most Indonesian schools implement the government curriculum. The curriculum is named curriculum 2013. Curriculum 2013 is a curriculum that applies in schools under the auspices of the government, the ministry of education. The curriculum 2013 provides two initial components, namely core competency, and basic competency. The core competency contains the essence of learning that must be mastered by students. Core competencies 1 and 2 are how learning in class, both material and activities can be related to the practice of religious teachings and the cultivation of students' good character. Core competence contains knowledge of facts, concepts, procedures, metacognition, and competence, while performance contains processing, reasoning, and presenting skills in the realm of the concrete and abstract language components (vocabulary and grammar) related to the development of what is learned by students or this part can be called the practical section. Basic competencies are derivatives of core competencies in the form of language skills and knowledge. However, student practices that are provided into teaching materials which are learned by students are acquired from students' classroom activities. All those components will drive into a syllabus that helps the teacher manage students' learning processes.

Similarly, the development of syllabus into a learning procedure, the ministry of religion launches the KMA no 184 the year 2019 program. This program is about the implementation of the curriculum in a school under the ministry of religion. The background of this program since the curriculum is still $90 \%$ under control by the government. The program focuses on teachers' creativity and innovation in managing the learning procedures. Not only does the regulation have issues on language practices at school but also the situation nowadays within the covid-19 outbreak forces teaching practices in the use of virtual meetings in which teachers and learners have been limited to online learning that requires technological aids in the implementation of each teaching-learning courses. Based on those backgrounds, a negotiated syllabus is needed to accommodate teachers and students' needs in the teaching-learning processes.

The English teaching and learning in Madrasah Aliyah (the Islamic senior high school level) is under the Ministry of education and the Ministry of Religion. The school has to follow both regulation of the two ministries. The curriculum and syllabus are designed by the ministry of education. Then in some cases, it should be matched with the regulation of the ministry of religion. The syllabus provides core and basic competence. English teachers could develop into an effective learning process based on the core and basic competence. This opportunity is ideally good for language teachers to create an existing English syllabus related to the students' needs. By negotiation, it will give a new perspective for English teachers to promising learning objectives. While for students, it will give them the new knowledge and language application of learning processes that are suited to students' ideas and experiences. Even though the syllabus is based on the government policy to achieve English teaching-learning objectives, the syllabus can effectively further be developed into a negotiated syllabus. 
JEASP

Journal of English for Academic and Specific Purposes

Volume 4 Number 1, June, 2021

The negotiated syllabus can be defined as a negotiation that involves the teacher and the learners working together to decide on many parts of the curriculum design process (Nation \& Macalister, 2010). This research is aimed to find the teachers' and students' perspectives to determine whether aspects of the syllabus may be negotiable. Thus, this research is important to be conducted in relation to the local perspective of teacher-students' language needs in which a negotiated syllabus is situated in the educational level of senior high school.

\section{LITERATURE REVIEW}

\section{Teacher and Students' Perspectives}

The study about teachers' perspective relates to the language teacher cognition research. It is also understood as the investigation of "what language teachers think, know, believe, and the relationships of these mental constructs to what teachers do in the language teaching classroom" ( Khosiyono, Pardjono, \& Priyana, 2019 ). Neil England adds this work which is normally informed by broader constructs of teachers' knowledge in general, as opposed to the specialized knowledge of language teachers (England, 2017). It is important in the way to get the teacher's perspective in the learning process. England (2017) explores about setting an agenda for language teachers' cognition research, supports this shift in perspective, or at least the addition of a collective perspective alongside the traditional focus on the individual as a teacher.

Similar to teachers' role in giving perspective, students are the key participants in the curriculum development projects and it is essential to collect as much information as possible about them before the project begins (Richard, 2001). The role of students in the learning process is needed as well. Nonetheless, to build that perspective, students should develop social and emotional skills. The students would expect to do better academically and the school climate would be more conducive to learning, students' interests, motivations, and points of view and encourage student responsibility and autonomy.

\section{Negotiated Syllabus}

In teaching English for high school students, the syllabus is the main role in the learning process. Teachers will always adopt the content of the syllabus to develop their teaching. In other words, the content of the syllabus determines how the process and objective of learning. The content of the syllabus is determined and made by the teachers under the provided curriculum including the materials and other parts of the syllabus. Ideally, the syllabus is given and explained to the students in the first meeting for preparing the whole learning process; however, in some cases it has not been applied yet. The benefit of giving a syllabus for students in the negotiation, the teachers and learners could negotiate to have the same objectives. This thought could be called a negotiated syllabus. 
JEASP

Journal of English for Academic and Specific Purposes

Volume 4 Number 1, June, 2021

Nation and Macalister (2010) define negotiated syllabus involves the teachers and learners working together to decide on many parts of the curriculum design process. It is supported by Richard and Schmidt (2010, cited in Montazeri 2015) negotiated syllabus is an approach to the development of a language course where learners' needs and preferences are taken into consideration during the course (Montazeri, Fekri, \& Hamidi, 2015).

Breen and Littlejohn (2000, cited in Nation \& Macalister, 2010) listed the situations where a negotiated syllabus is unavoidable because teachers and students have different knowledge backgrounds. The allocated teaching-learning time is short; therefore, the most useful choices must be made in the way of diverse differences of learners' language learning needs synthesized in their common ground. The synthesis starts from initial needs analysis which is possibly adapted in their most intended learning objectives related to students' past experiences and open-ended and exploratory language courses.

From those situations, Clark ( 1991, cited in Smallman 2020) argued that the basic principle of the negotiated syllabus is that students have important roles of teaching-learning materials in which teachers and students can select what and how to learn the materials altogether. Students have their own voice to adapt content materials and even the assignments given to them, which should suit to their learning needs (Smallman, 2020). Therefore, according to the Indonesian context, students are hardly invited to do a negotiated syllabus. The teacher takes the main role in the learning process to prepare everything. Meanwhile, students mostly receive everything from teachers. By doing negotiation or discussion, however, the core idea of the negotiated syllabus can accommodate students' needs and their participatory learning activities may be significantly improved.

The curriculum provided by the ministry of education, however, cannot be negotiable in its all parts. Boon (2011) mentioned several areas in the syllabus that could be a source to be negotiated for both teachers and students. The areas are course content, lesson aims, sequencing, material, homework, evaluation, methodology, groupings, and error correction.

\section{METHOD}

This study uses a qualitative descriptive. According to Creswell (2012), qualitative research explores the problem and detailed understanding of a concept phenomenon as the key concept to develop. According to Lambert and Lambert (2012), descriptive qualitative is a comprehensive summary of certain daily experiences encountered by an individual or group.

Therefore, the qualitative approach and descriptive method are used to describe every single information derive from the instruments where the data retrieved is analyzed and concluded from the perspective of the researcher. The participants of this research are four English teachers and twenty senior high school students. The background of the teachers is graduated with a Bachelor degree in English department. 


\section{JEASP}

Journal of English for Academic and Specific Purposes

Volume 4 Number 1, June, 2021

They have quite a long experience in teaching English for Madrasah Aliyah (senior high school). Then, the students are chosen randomly. Twenty students were divided into ten male and ten female students. The students were selected based on English teachers' points of view related to their English competence and participation in the learning process.

Participants' general information

Table.1 Teachers' General Information

\begin{tabular}{cccccc}
\hline No & Participants & Age & Gender & Education & $\begin{array}{c}\text { Teaching } \\
\text { Experience }\end{array}$ \\
\hline 1 & Teacher 1 & 26 & Female & S 1 English Department & 2 years \\
2 & Teacher 2 & 26 & Female & S 1 English Department & 4 years \\
3 & Teacher 3 & 31 & Female & S 1 English Department & 4 years \\
4 & Teacher 4 & 34 & Female & S 1 English Department & 8 years \\
\hline
\end{tabular}

Table.2 Students' General Information

\begin{tabular}{clcc}
\hline No & Participants & Age & Gender \\
\hline 1 & Student 1 & 17 & Male \\
2 & Student 2 & 17 & Male \\
3 & Student 3 & 17 & Male \\
4 & Student 4 & 16 & Male \\
5 & Student 5 & 18 & Male \\
6 & Student 6 & 16 & Male \\
7 & Student 7 & 16 & Male \\
8 & Student 8 & 17 & Male \\
9 & Student 9 & 15 & Male \\
10 & Student 10 & 17 & Male \\
11 & Student 11 & 17 & Female \\
12 & Student 12 & 16 & Female \\
13 & Student 13 & 16 & Female \\
14 & Student 14 & 16 & Female \\
15 & Student 15 & 16 & Female \\
16 & Student 16 & 17 & Female \\
17 & Student 17 & 16 & Female \\
18 & Student 18 & 16 & Female \\
19 & Student 19 & 16 & Female \\
20 & Student 20 & 17 & Female \\
\hline
\end{tabular}

The data were collected by conducting a questionnaire in the form of open question items. Both teachers and students could respond the item questions related to the negotiated syllabus freely (in Indonesian and translated into English) to determine what aspects of the syllabus interestingly to be negotiable.

\section{FINDINGS AND DISCUSSION}


JEASP

Journal of English for Academic and Specific Purposes

Volume 4 Number 1, June, 2021

The participants in the negotiated syllabus are teachers and students. Teachers' and students' perspectives becomes the essential points to be researched in which parts of the syllabus could be negotiated by teachers and students. The open-ended questions guidelines to find perspectives, the areas are course content, lesson aims, sequencing, material, homework, evaluation, methodology, groupings, and error correction (Boon, 2011).

\section{Course Content}

The teacher and students' participation are very essential at the beginning of the learning process. Teachers stated that the course should cover what students need to study.

"Yes, the negotiation is needed to be able to correlate with the students' learning condition at classroom and to achieve their learning goals."

Along with the teachers' teaching objectives, three students' perspectives were chosen as representative of other students' points of view. A student does not agree with the negotiated syllabus for the course content because he thought that the course content is the syllabus designed by the government. Teachers and students should follow the regulation.

"No, I think, it is already in the government regulation we should follow that"

Meanwhile, two students agree on the negotiation. They realized that negotiation is freely conducted throughout the course content. The students will prepare for what material they are going to learn. Students also could give their opinion related to their learning needs in the material contents.

"I think it can be negotiated, so we will know the materials, the topic, etc."

"Yes, so we could give our opinion that maybe one material is not useful for us"

\section{Lesson Aim}

Teachers and students need to negotiate to achieve the lesson aims and objectives. The teachers' and students' perspectives are related to the negotiation in the form of lesson aim.

"Even though it has been decided in core and basic competence of curriculum but we have to make sure the implementation both knowledge and skills applied not only in classroom activities but also in the students' daily activities at home."

"Yes, so we could what we want from the English learning activities"

"T want to improve my skills that teachers should help us" 


\title{
JEASP
}

Journal of English for Academic and Specific Purposes

Volume 4 Number 1, June, 2021

\section{"I don't know"}

\section{Sequencing}

Based on the results of open-ended questions, teachers believe that sequencing should be negotiated. However, students have mixed answer related to the sequencing topics

\author{
"I want the teacher to teach us from the easy level to hard one." \\ "If we could discuss that I will ask the teacher to give exercises after teaching the lesson is over." \\ "I think it's the teacher's duty"
}

\section{Material}

Teachers believe that negotiation should be implemented between teachers and students in relation to material development. Students, however, had a variety of responses. Some of them believe that developing course material belongs to teachers' responsibilities.

"Yes sure, so we can decide what really important for us"

"No, I think, we don't need to discuss it"

"Teacher should decide"

\section{Homework}

Teachers and students should negotiate what and how each homework should evaluate and significantly impact on students' learning development. Based on the result of the open-ended questions, students responded that each assignment will be effectively accomplished when students can create their own questions and answers with teachers' guidance, such as topics, assignment loads, and time.

"Of course, it needs negotiation, so the objectives of homework will be understood easily"

"Yes, giving too much homework sometimes not effective"

"The negative one is maybe students will say no for homework, this is our duty to convince them"

"Yes, I think, so we can learn something different at home. I will ask for fun homework"”

"Yes sure, I don't like it when the teacher gives too much homework because It makes me lazy to complete it"

\section{Evaluation}

Both teacher and students argued that negotiation in the form of evaluation can be transparently conducted since students need to identify their strengths and weaknesses of corresponding topics and sub-topics they have learned. 
JEASP

Journal of English for Academic and Specific Purposes

Volume 4 Number 1, June, 2021

'T think so, although students will get a chance to do a protest when they get a bad evaluation. We need to do it'

"No, I think, it is under the control of teachers"

"I think it is for the teacher"

"It is also needed. I can learn and understand more about the material before the evaluation from the teacher"

\section{Methodology}

Methods are the important thing in learning activities that both teacher and students believe to negotiate. Brown (2000) mentioned several methods in language teaching such as GTM, Audiolingual, Direct method, etc. that method should be introduced to the students to give them the knowledge in the way of the learning process.

"Whatever the methods are good but we need to do collaboration both pairs or group work."

"It is interesting if there is a negotiation with students, students will learn also some methods in learning English"

"I think it's good. So, a teacher will know what method that suitable for the learning. I don't like monotonous learning activities".

\section{Groupings}

Grouping is needed to discuss since this area includes the students learning activities. students at the high school level have a problem in the grouping. Both teacher and students believe the area of grouping should be negotiated.

"Sometimes we need to discuss with students what grouping they want to"

"Yes sure, so the teacher will know how to divide us in a group work, I like when I am with the smart one"

\section{Error Correction}

In the area of error correction, two teachers state that it should not be negotiated. Teachers thought that it is in the area of teachers' work. The students should be involved in the process of providing feedback for each error of students' work. The teachers and students teach and learn the situation altogether.

"No, I think, it's one of the teacher's duties"

"It is necessary. Students should know each error they made and we believe they take a new lesson from each error."

However, the students' perspectives have varied responses. For some students need to know the error correction, but others think the correction is not necessary. The following statements are the students' responses related to the error correction when English syllabus was once negotiated, but resulted in a variety of responses. 
JEASP

Journal of English for Academic and Specific Purposes

Volume 4 Number 1, June, 2021

\section{"No, I think, I don't like it if my friends know my mistakes" \\ "T think it is important. So, we will know our mistakes and know the right one"}

The English language teaching in Indonesian contexts is English as a foreign language (EFL). There will be so many challenges for teachers and students to get their teaching and learning effective. Along with the development of learning English, the ministry of education provides the curriculum in the form of core and basic competence. The curriculum becomes the main source for language teachers to develop their own English syllabus. Related to the Boon's research (2011), he mentioned that the syllabus documents remain blank pages when teacher-students' negotiation does not meet their needs. Therefore, teachers and students could discuss and decide the syllabus to support the English learning processes through fluid and flexible negotiations.

The open-ended questions focus on teachers' and students' perspectives towards negotiated syllabus in learning English. Several aspects of the syllabus should be negotiated. In a negotiated syllabus the role of teachers and students is important. Teachers and students are the participants in the learning processes. Nation and Macalister (2010) claimed the negotiated syllabus involves teachers and students working together. In the area of syllabus Boon provides several areas that teachers and students could do their negotiation The areas are course content, lesson aim, sequencing, material, homework, evaluation, methodology, grouping, and error correction (Boon, 2011).

The open-ended questions reveal the arguments in several areas of negotiations. All teachers believe the negotiated syllabus could be done in the area of course context, lesson aim, sequencing, methodology, and grouping. The teachers' perspective is related to those areas since teachers need the students' opinion in the form of their need, lack, and want. Teachers believe that getting students' information through negotiation can help teachers design language materials. They could develop an effective syllabus in teaching English. However, some teachers did debate material, homework, evaluation, and error correction. All aspects are relevant to be negotiated. But, some teachers' perspectives showed disagreement that the negotiated syllabus could be done in those areas. They believe that area is in the teachers' work. However, students do not need to be involveds in negotiation.

Along with the teacher's perspective, student's perspectives are highlighted in this research findings. Both teachers and students got the same open-ended questions. The findings were that of students' perspectives related to the eleven areas showed their learning beliefs. They realized that they should know and give their ideas to the teachers in the syllabus design. It is important since it is related to their need, wants, and lack, but not for several areas such as course content, lesson aim, sequencing, material, grouping, and error correction. Some students believe that they do not need to participate in the negotiation since those areas are already designed by teachers due to their teaching responsibilities.

In sum, both teachers and students provide feedback related to the negotiated syllabus through the eleven areas according to Andrew Boon's. They believe negotiation is needed to develop the syllabus, although 
JEASP

Journal of English for Academic and Specific Purposes

Volume 4 Number 1, June, 2021

there are debates in several areas. Since, it is in the form of perspective that relates to the teacher-students' beliefs.

\section{CONCLUSION}

This study aimed to find out the teacher's and students' perspectives towards negotiated syllabus in learning English. Several aspects may be interested to be negotiated. In a negotiated syllabus, the role of teachers and students are the main participants. Eleven areas can be discussed according to Boon (2011). It can be concluded that both teachers and students believe the eleven areas could be negotiated. However, there are some debates in several areas. According to some teachers' perspectives, the area of material, homework, evaluation, and error correction do not need to negotiated. Besides, according to some students, the area of course content, lesson aim, sequencing, material, grouping, and error correction are the teachers' work. Students do not need to participate their involvement in the negotiated syllabus due to teachers' responsibilities.

\section{REFERENCES}

Boon, A. (2011). The negotiated syllabuses: Do you want to? In Case studies in language curriculum design (1ed), J. Macalister. New York: Routledge, pp.166-177.

Brown, H.D. (2000). Teaching by principles: An interactive approach to language pedagogy, Second Edition. London: Pearson-Longman.

Creswell, J.W. (2012). Educational research: Planning, conducting, and evaluating quantitative and qualitative research (4th ed). USA: Pearson Education.

England, N. (2017). Developing an interpretation of collective beliefs in language teacher cognition research. TESOL Q., vol. 51, no. 1, pp. 229-238.

Khosiyono, B.C.K, Pardjono, \& Priyana, J. (2019). Teachers' Perceptions towards the use of maritime English textbooks in vocational School. In THE JOURNAL OF ASLA TEFL Vol. 16, No. 3, Fall 2019, 10421050http://dx.doi.org/10.18823/asiatefl.2019.16.3.21.1042

Lambert, C.E. \& Lambert, V.A. (2012). Qualitative descriptive research: An acceptable design. Pasific International Journal of Nursing Research Vol 4, 255-256.

Montazeri, M., Fekri, N. \& Hamidi, H. (2015). Negotiated syllabus: A realization of learner autonomy. Journal of Language Teaching: Theory and Practice, 1 (1), 9-14.

Nation, L.S.P \& Macalister, J. (2010). Language curriculum design. New York: Routledge Taylor \& Francis Group.

Richards, J.C. (2001). Curriculum development in language teaching. New York: Cambridge University Press. 


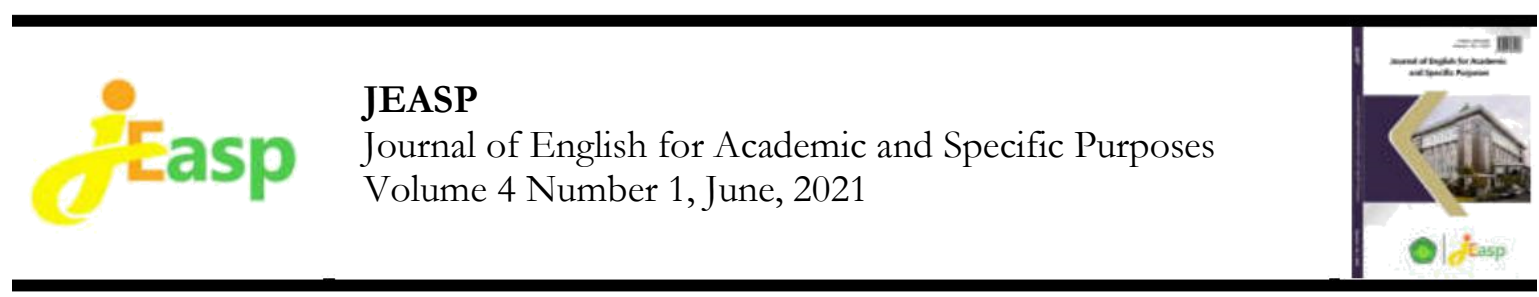

Smallman, S. (2020). The Negotiated Syllabus: How to Create Community in Online International Studies Classes. International \& Global Studies Faculty Publications and Presentations. 47.https://pdxscholar.library.pdx.edu/is_fac/47 